\title{
Assessment of the changes in the yields of millet crop under different scenarios of climate change using DSSAT model
}

\author{
Halimatou A. TOURE ${ }^{1,3}$, Idriss SERME ${ }^{*}$, Kalifa TRAORE ${ }^{2}$ and \\ Nicholas KYEI-BAFFOUR ${ }^{3}$ \\ ${ }^{I}$ Institute of Environment and Agricultural Research, Burkina Faso. \\ ${ }^{2}$ Rural Economic Institute, Soil-Water-Plant Laboratory, Sotuba. Bamako, Mali. \\ ${ }^{3}$ Department of Agricultural Engineering, KNUST, Kumasi, Ghana. \\ *Corresponding author; E-mail: sermeidriss@yahoo.fr
}

\begin{abstract}
Agriculture in Mali is vulnerable to climate change. Rainfall remains uncertain for the future, while the increase in temperature is almost a certainty. The objective of this present study was to assess the performance of DSSAT model in simulating the yield of two millet varieties in two agro-ecological zones of Mali under different scenarios of climate change. The performance of two millet varieties in two agro-ecological zones of Mali was assessed using Decision Support System for Agro-Technology Transfer (DSSAT) model under different climate scenarios. Two year experiments were therefore conducted at The Agricultural Research Station of Sotuba located in Sudanian zone and Cinzana in Sahelian zone according to a randomised complete block design with 4 replications. The treatments included Control, Manure 23:10:17 (5000 kg/ha) NPK 15: 15: $15(50 \mathrm{~kg} / \mathrm{ha})$ and NPK+Manure. DSSAT model was used to simulate crop grain yields under two different weather conditions (historical and future). Millet grain yields were higher under the simulations with historical weather data than the simulations with climate change scenarios. Simulation of climate change effects on millet grain yield showed that all scenarios underestimated crop yield compared to the baseline for all treatments and all varieties (CHO, Sanioni, Sosat and IBV8001) All of the varieties showed lowest grain yields under the four treatments for ACCESS1-0 (Hot-Wet) among the scenarios. Based on these findings, it is suggested that, policy should be developed to enhance farmers' adaptation strategies in the Sudanian and Sahelian zones of Mali. (C) 2018 International Formulae Group. All rights reserved.
\end{abstract}

Keywords: Agriculture, Rainfall, Temperature, Treatments, Model, Simulation, Grain Yield.

\section{INTRODUCTION}

In several regions in the world, climate will probably adversely affect food production, especially in developing countries where a large fraction of the population already faces permanent hunger (Lobell and Burke, 2008). According to Dai and Trenberth (2004) in sub-Saharan West Africa, the observed decrease in rainfall has been associated with an increase in temperature since the 1970s which has led to a decline in production (Barriose et al., 2008; Traore et al., 2013). IPCC (2013) showed that the projection of climate by the end of the century shows an increase of temperature by 1.1 to 4.8 ${ }^{\circ} \mathrm{C}$ and an increase of contrast between wet and dry season for the Sahelian region. Many studies assessed the impact of current and the 
future climate effect on crop production (Roudier et al., 2011; Sultan et al., 2013), and indicated that crop yields would decrease by $15 \%$ probably because of the effect of temperature decrease and the length of crop growth cycle and increase water stress through higher evaporation losses, even though the rainfall amount remains unchanged (Schlenker and Lobell, 2010). The impact of crop yield studies for Africa illustrates a wide dispersion of changes in yields ranging from $50 \%$ to $90 \%$ under various climate change scenarios (Roudier et al., 2011), while the reported changes in crop yields are mostly negative (Challionor et al., 2007). The projected impact is wider in the SudanoSahelian countries in West Africa, with an average yield loss of $18 \%$ compared with an average yield loss of $13 \%$ in the southern Guinean countries (Sultan et al., 2013). This difference is likely caused by the warmer and drier climates in the northern countries.

Agriculture in Mali is very vulnerable to climate change. Rainfall remains uncertain for the future (Sultan and Janicot, 2003), while the increase in temperature is almost a certainty (Schwartz and Randall, 2003). This is a major challenge for agriculture which depends almost entirely on rainfall, as average temperatures would be close to the highest values ( 1 to $2,75{ }^{\circ} \mathrm{C}$ or more by 2030) (Oxfam, 2007) that could be harmful to the growth and development of crops. Crop production in Mali is essentially characterized by subsistence farming based on millet and sorghum in the Central and Northern region, Cotton and rice are the main cash crops in the southern regions and the centre. The yield of rice and cotton have seen a considerable increase (average yield for cotton: 1 t/ha and rice: $5 \mathrm{t} / \mathrm{ha}$ ), while those of rainfed food crops (sorghum $0.8 \mathrm{t} / \mathrm{ha}$ and millet, $0.7 \mathrm{t} / \mathrm{ha}$.) evolved slowly during the last 50 years, despite being the staplefood for more than $80 \%$ of the population (DNS, 1995).

In Mali, future crop yield will vary between $-17 \%$ and $+6 \%$ at the national level (Butt et al., 2005). Negative impacts of climate change on crop productivity increase in severity as warming is intensifying and; emphasizes the importance of coping with global warming (Traoré, 2014). The IPCC's fifth Assessment Report (AR5) presents new evidence of climate change (IPCC, 2013) and adaptation cropping systems to the likely climate change. Several adaptation options that help Malian farmers to cope with current climate variability could be considered (Traoré, 2014). Cropping systems are in general link to: water management, fertilisation, crop land increases, asset management, income as diversification of activities and migration (Chuku and Okoye, 2009). Changing the sowing date to the beginning of the rainy season is another common adaptation strategy by farmers in the semi-arid regions (Muller et al., 2010). Studies for West Africa's crop simulation studies showed that sowing date and early mature cultivar areadaptation strategies that can reduce the negative impact of the climate change crop yields (Tingem and Rivingto, 2009). These authors also showed a simulation maize and sorghum yield results which will decrease by $15 \%$ and $40 \%$ respectively due to climate change. This could be converted to an increase of $32 \%$ and $18 \%$ respectively when different varieties with a longer crop growing period was used. Similarly, Butt et al. (2005) argued that by implementing adaptive responses such as the use of high-temperature-resistant crop varieties together with addressing soil fertility decline and economic gains could exceed losses caused by climate change in Mali.

Crop models simulation is the complex interaction between soils properties, genetic management factors genetics, pest and weather that influence performance of the crops. Simulation of crop modelling has developed over several years critic with advances in crop physiology, ecology and computing technology (Mukkar and Hassana, 2011). However, among the numerous crop growth models, the most largely used are the Decision Support System for AgroTechnology Transfer (DSSAT) model. It was designed to stimulate development, growth 
and yields of crop growing on a uniform area of land as well as the changes in carbon, nitrogen and soil water that take place under the cropping system over time (Jones et al., 2003). An important task in models experiments is the testing of the performance of the model in a large range of circumstances in oder to identify their scope of limitations and validity (Mukktar and Hassana, 2011). The objective of this present study was to assess the performance of DSSAT model in simulating the yield of two millet varieties in two agro-ecological zones of Mali under different scenarios of climate change.

\section{MATERIALS AND METHODS Crop model}

The Decision Support System for Agro-technology Transfer (DSSAT)/CSM simulates growth, development and yield of a crop growing on an uniform area of land under prescribed or simulated management as well as the changes in soil water, carbon, and nitrogen that take place under the cropping system over time. A detail description of the model has been provided by Ritchie and Alagarswamy (1989) and Hoogenboom et al. (2003).

\section{Selection of pearl millet varieties}

DSSAT model is variety-specific and is able to predict millet yield and millet response to different environmental conditions. In projecting crop growth and yield, the model takes into account crop management, genetics, effect of weather and soil water, $\mathrm{C}$ and $\mathrm{N}$. The model uses a detailed set of crop specific genetics coefficients, which allows the model to respond to diverse management and weather conditions. However, in order to get trustworthy results from the model simulations, it is important to have appropriate genetic coefficients for the selected cultivars. The two pearl millet varieties SANIONI and CHO for Sotuba site and IBV8001 and SOSAT for Cinzana have been selected in the present study. A specific cultivar coefficient for the genotypes used in these experiments was not in the list of cultivars available within the model. The cultivar coefficients were adjusted, until main development and growth stages were made for parameters of the development and growth, the aim was sensitivity analyses of the model and improvement of the genetic coefficients. The coefficients were decreased or increased if needed using a small step.

\section{Soil and crop management input}

Soils in these zones are mainly sandy and loamy of low fertility and seasonally waterlogged or flooded clays (FAO, 1993). They are classified as Lixisol according to FAO (1993) soil classification. Soil-related modules were parameterized mainly with measured data from experiments carried out under optimal growth conditions, and from related literature. Disturbed and undisturbed soil samples were taken in soil depths $(0-10$, $10-20,20-40,40-120 \mathrm{~cm})$ prior to sowing, were analysed for organic carbon (OC\%), $\mathrm{pH}$ in water, and particle size distribution as described in Hoogenboom et al. (1999). Input data related to soil characteristics include soil texture, number of layers in soil profile, soil layer depth, $\mathrm{pH}$ of soil for each depth, clay, silt and sand contents, organic matter, cation exchange capacity, etc. The soil profile data used in the parameterization of the model are presented in Table 1 and Table 2.

\section{Experiment for crop yield simulation model calibration}

In the present study, DSSAT v 4.6 (CERES-Millet) (Jones et al. 2003) was used to simulate crop yields as a function of current as well as future climatic conditions. Data from an experiment carried out in 2013 and 2014 at Sotuba and Cinzana Agronomic Research Station under rainfed conditions were used tocalibrate. The models. Daily weather data during the growing season were obtained from observations at the experimental stations. These included 
minimum and maximum temperatures, rainfall and sunshine hours which in turn are used to estimate solar radiation. Phonological data including planting date, date of flowering, date of start grain filling and date of physiological maturity were collected. These were noted when $50 \%$ of plant population per plot attained each of these stages. The calibration was done using trial and error method of iteratively adjusting the parameters to obtain as close as possible the simulated and observed values of phenology (i. e. anthesis and maturity dates) and grain and biomass yields.

The fertilizers treatments used were: T1 Control (no application); T2 MANURE of 23:10:17 (5000 kg/ha); T3 NPK of 15: 15: 15 $(50 \mathrm{~kg} / \mathrm{ha})$ and T4 combination of NPK + MANURE The experiments were conducted in a randomised complete block design (RCBD) with four replications in a plot size of $10 \mathrm{~m} \times 4.2 \mathrm{~m}$. The varieties evaluated at Sotuba station were Sanioni, an improved local variety and Cho, a local variety while at Cinzana station Sosat, an improved variety form IER /ICRISAT and IBV8001, and an improved variety from ICRISAT were used.

\section{Modelling of effect of climate change and} variability on millet grain yield

For climate change impact study, historical weather data were derived from the Agronomic Research Station for both sites for the period of 30 years from (1983 to 2012) and another 30 years' period projected weather from 2040 to 2070 . The historical data were used to simulate the variability of grain yield on different pearl millet varieties considering the different treatments and also used as baseline for the projected scenarios. Five scenarios were used based on GCMs (Global Circulations Models), where CMCCCMS, CESM1-BGD, CCSM4, ACCESS1-0 and MRI-CGCM3 were described as Colddry, Hot-dry, Cold-wet, Hot-wet and Middle respectively. Cold and hot were defined as changes in temperature while wet and dry as changes in rainfall. Future weather scenarios used in the simulation for grain yields experiments were:

- Temperature increase $\left(1.4{ }^{\circ} \mathrm{C}\right)$ and (no change) in rainfall,

- Temperature increase in $\left(2.4{ }^{\circ} \mathrm{C}\right)$ and $10 \%$ decrease in rainfall,

- Temperature increase in $\left(1{ }^{\circ} \mathrm{C}\right)$ and $30 \%$ increase in rainfall,

- Temperature increase in $\left(2.4{ }^{\circ} \mathrm{C}\right)$ and $30 \%$ decrease in rainfall,

- Temperature increase in $\left(1.6{ }^{\circ} \mathrm{C}\right)$ and $15 \%$ decrease in rainfall.

The five GCMs were chosen based on their use in previous studies in the region and their better representation of projected climate, in terms of temperature and rainfall patterns in West Africa. The simulations were made using a fixed concentration of atmospheric [CO2] of $499 \mathrm{ppm}$ for the baseline (the value reported for the year 2010 in the fourth assessment report of IPCC).

\section{Statistical analysis \\ Experimental treatment}

The effect of the treatments and their interactions were analysed for the four following parameters: plants height, 1000 grain mass, grain yield and straw yield, with Analysis of Variance (ANOVA) performed with GENSAT V.9 Discovery Edition 4, Release 10.3DE (PC/Windows 7), Copyright 2011, VSN International Ltd. (Roth Amsted Experimental Station).

Using the General Treatment Structure (in Randomized Complete Blocks), ANOVA model included treatments, year and their interactions. Duncan Significant Difference (DSD) test was used for postANOVA multiple comparisons $(\mathrm{P}<0.05)$ between means. Duncan significant tests were chosen because it can be used on raw data or in conjunction with an ANOVA test (Random complete block). 
Data for model evaluation

The calibrated model was evaluated by comparing observed values for parameters of grain yield with those from model simulations. Model performance was assessed through various statistical parameters viz. Coefficient of correlation, standard deviation, root mean square error (RMSE), relative error, model efficiency, were used to evaluate overall model performance (Loague and Green, 1991; Lecina et al., 2003; Dust et al., 2000; Ali et al., 2004; Liu et al., 2011)

- Root Mean Square Error (RMSE)

The Root Mean Square Error also called the Root Mean Square Deviation (RMSD), is a frequently used measure of the difference between values predicted by a model and the values actually observed from the environment that is being modelled. The individual differences are also called residuals and, the root mean square serves to aggregate them into a single measure of predictive power;

RMSE $=\left(\sum_{i=1}^{n} \frac{\left(P_{i}-O_{i}\right)^{2}}{n}\right)^{\frac{1}{2}} \times \frac{100}{O_{\text {mean }}} \geq 0$ with the optimum $=0$..... . Equation 1

Where:

$P i$ stands for the predicted values, $O i$ for the observed values and $O$ for the observed mean values. RMSE measures the difference between simulated and observed data, according to Loague and Green (1991).

- Relative error (RE)

$\mathrm{RE}=(R M S E \div \overline{\mathrm{y}}) \times 100$ Equation 2 Where, $\bar{y}$ is the mean of the observed values.

- Model Efficiency

$\mathrm{EF}=\frac{\sum(\text { measured }-M M)^{2}-\sum(\text { simulated }- \text { measured })^{2}}{\sum(\text { measured }-M M)^{2}} \ldots$ Equation 3

Where, MM=Measured mean.

Table 1: Chemical properties at Cinzana site for model evaluation experiment.

\begin{tabular}{lcccccccc}
\hline Depth (cm) & $\mathbf{p H}(\mathbf{w})$ & $\mathbf{p H}(\mathbf{K C})$ & Sand \% & Silt \% & Clay \% & OM \% C & N \% & CEC meq/100mg \\
\hline $0-10$ & 5.51 & 4.54 & 81.67 & 11.00 & 7.17 & 1.89 & 0.15 & 2.62 \\
$10-20$ & 5.44 & 4.37 & 76.67 & 9.67 & 13.00 & 1.76 & 0.14 & 3.43 \\
$20-40$ & 5.45 & 4.35 & 70.17 & 9.00 & 20.83 & 1.46 & 0.15 & 3.00 \\
$40-120$ & 5.45 & 4.35 & 70.17 & 9.00 & 20.83 & 1.46 & 0.15 & 3.00 \\
\hline
\end{tabular}

Table 2: Chemical properties at Sotuba site for model evaluation experiment.

\begin{tabular}{lcccccccc}
\hline Depth (cm) & pH (w) & pH (KC) & Sand \% & Silt \% & Clay \% & OM \% C & N \% & CEC meq/100mg \\
\hline $0-10$ & 5.77 & 4.83 & 72.06 & 21.28 & 6.59 & 1.32 & 0.88 & 5.47 \\
$10-20$ & 5.70 & 4.63 & 70.13 & 19.25 & 10.69 & 1.24 & 0.85 & 5.10 \\
$20-40$ & 5.75 & 4.61 & 66.59 & 19.19 & 14.13 & 1.14 & 0.73 & 5.44 \\
& 5.75 & 4.61 & 66.59 & 19.19 & 14.13 & 1.14 & 0.73 & 5.44 \\
\hline
\end{tabular}




\section{RESULTS}

Validation and evaluation of the CSMCERES millet model for Sotuba and Cinzana sites

The model adequately simulated the grain yields. The $R^{2}$ values of the linear regression of simulated versus observed grain yields for Sotuba site for genotype $\mathrm{CHO}$ were 0.98 and 0.88 for 2013 and 2014 respectively. That of genotype SANIONI were 0.96 in 2013 and 0.92 in 2014) for 2013 and 2014 respectively. While in the Cinzana site, $\mathrm{R}^{2}$ values were: genotype SOSAT (0.68 and 0.99 ) and genotype IBV8001 (0.91 and 0.96) for 2013 and 2014 respectively. The correlation had intercepts not significantly different from zero and the slopes not significantly different from one $(\mathrm{P}>0.05)$.

The coefficient of determination $\left(\mathrm{R}^{2}\right)$ for the grain yields of all genotypes are most often, within the acceptable limit $\left(R^{2}>0.5\right)$. The values of $\mathrm{R}^{2}$ for all of the genotypes indicated good correlation between the observed and simulated yields (Figures $1 \mathrm{a}, \mathrm{b}$, $c$ and d). The highest grain yield observed corresponded to the highest grain yield simulated and vice versa.

Figure 1 shows that for the two years period of experiment results for 2013 and 2014 two sites, the DSSAT models caught yields variability for different genotypes. Therefore, the year by year analysis, of the result presents very good correlation in Sotuba site with $\mathrm{R}^{2}=0.98$ and 0.88 for $\mathrm{CHO}$ genotypes and for SANIONI $\mathrm{R}^{2}=0.96$ and 0.92 in 2013 and 2014 respectively. Similar result was found in Cinzana site with genotype Sosat having $\mathrm{R}^{2}=0.68$ and 0.99 and IBV8001 $\mathrm{R}^{2}=0.91$ and 0.96 , in 2013 and 2014 respectively. Therefore, in both years and among genotypes and each research site the performance $\left(\mathrm{R}^{2}\right)$ of the model was high and there was a systematic overestimation of millet yield. But with SOSAT genotype there was difference between the two years, 2013 (acceptable range obtained) and 2014 (overestimated of the yields)

Table 3 showed the values of root mean square error (RMSE) of the site of Cinzana for the grain yield for the genotypes SOSAT and IBV8001. During the experimental year 2013, forgenotypes SOSAT and IBV8001 presented RMSE values of (19.9 and $16.9 \%$ ) with relative errors (of 5.2 and $5.7 \%)$ respectively. For the experimental year 2014 genotypes SOSAT and IBV8001 showed RMSE values of(11.3 and 19\%) with relative errors (2.8 and $4.2 \%)$ respectively. The overall value above $50 \%$ indicated good fit of the model. Thus for genotypes SOSAT and IBV8001 in 2013 the 14.4 and $51.9 \%$ and 2014 the model efficiency (50.0 and $41.1 \%$ ) indicated an overall good performance of the model for the site of Cinzana.

The site of Sotuba (Table 4) presented root mean standard error (RMSE) values for grain yield of 19.4 and $20.0 \%$ for genotypes SANIONI and CHO respectively in 2013 with the relative errors of 5.4 and $5.6 \%$ respectively. In 2014, values of RMSE recorded were 16.6 and $20.3 \%$ for varieties SANIONI and CHO respectively with relative errors of 4.4 and $5.1 \%$ respectively. The overall value above $50 \%$ indicated good fit of the model for varieties SANIONI and CHO in 2013 (85.3 and 14.4\%) and 2014, the model efficiency (70.1 and 68.9\%) indicated an overall good performance of the model for the site of Sotuba.

Simulated millet grain yield under climate variability over $1983-2012$ in the site of Sotuba and Cinzana

Since the model was able to give good simulation of millet grain yield for all of the treatments for both sites for both varieties, the grain yields were simulated for the period 1983 - 2012 under historical weather conditions. High variability was observed in the grain yield over the past 30-years simulation period for all of the treatments (Figure 2). For both sites and all varieties, the trend of the simulated millet grain yields was Control < Manure $<$ NPK $<$ Manure+NPK. Furthermore, the lowest grain yields varied between 200 and $300 \mathrm{~kg} / \mathrm{ha}$ whereas the highest values were about 1500 and 2250 $\mathrm{kg} / \mathrm{ha}$ for the site of sotuba and Cinzana, respectively.

The study first established where and how much crop yield varied with the varieties and then identified how much of the year to year variation in crop yields with the different 
treatment was explained by year to year variation in the climate. In general, the coefficients of variation (CV) or yield variability normalized by mean yields were low in the site of Cinzana with IBV8001variety under NPK and MANURE+NPK treatments by 14 and $12 \%$, respectively. Similarly, the CV for SOSAT variety were 18 and $14 \%$, respectively with the same treatments at the same site (Table 5). As far as Sotuba is concerned, the CV were slightly high for $\mathrm{CHO}$ variety with $\mathrm{CV}$ of 23 and $18 \%$ under the NPK and MANURE+NPK treatments, respectively. However, SANIONI variety showed low variability ( $14 \%$ for both) under the same treatments (Table 6). Conversely, higher variability was found in Control and Manure in both site and for both varieties. High CV (30\% for both treatments), which indicates the greatest variability in millet grain yield, were observed in the site ofSotuba with SANIONI variety under the Control and Manure treatments (Table 6). Globally, the highest yield variability was found in the site of Sotuba.

\section{Effect of climate change scenarios on millet grain yield on the sites of Cinzana and Sotuba}

Simulation of climate change effects on millet grain yield showed that all of the scenarios underestimated crop yield compared to the baseline for all treatments and both varieties in the site of Cinzana (Figures 2a and 2b). For the variety IBV8001, the Control and Manure treatments had the lowest grain yield $(<1000 \mathrm{~kg} / \mathrm{ha})$ whereas NPK + Manure and NPK yielded over $1000 \mathrm{~kg} / \mathrm{ha}$. Crop yield under the Control and NPK treatments were closer among the scenarios and compared to the baseline. However, the outputs for all of the scenarios with NPK+ Manure and Manure treatment were lower compared to the baseline, which reached about $2000 \mathrm{~kg} / \mathrm{ha}$. As indicated in Table 5, ANOVA test and Least Significant Difference test (LSD) confirmed the significant differences $(\mathrm{P}<0.05)$ noticed between the scenario outputs under all treatments. Among all scenarios, ACCESS1-0 (Hot-Wet) showed the lowest grain yields under the four treatments (Figure 3a). The percentage of grain yields decrease as simulated by the scenarios varied between $3 \%$ for the Control and NPK under CMCC-CMS, and $24 \%$ for Manure under ACCESS1-0 (Figure 3a). Slight increase of $1 \%$ was observed with NPK treatment under CESM1BGD scenario.

Regarding the SOSAT variety, all of the scenarios for the four treatments estimated low grain yield compared to the baseline, except the Control and NPK treatment for which the CMCC-CMS (Cold-Dry) and CESM1 -BGC (Hot-Dry) yielded higher grain yield than the baseline with low probabilities (Figure 3). Similar to the IBV8001 variety, all of the scenarios under NPK + Manure and Manure treatments simulated lower grain yields compared to the baseline. The lowest grain yields were $200 \mathrm{~kg} / \mathrm{ha}$ for Control and Manure treatments, and $900 \mathrm{~kg} / \mathrm{ha}$ for NPK and NPK + Manure treatments. ANOVA and LSD test revealed significant differences ( $\mathrm{P}<$ 0.05 ) among the scenario outputs for Control, NPK + Manure and Manure treatments (Table 6). Meanwhile, no significant difference was observed among the average grain yields for all of the scenarios under NPK treatment. Similar to IBV8001 variety, SOSAT showed lowest grain yields under the four treatments for ACCESS1-0 (Hot-Wet). The grain yields decrease reached $1 \%$ for the NPK treatment under CCSM4, and $40 \%$ for Manure treatment under ACCESS1-0 (Figure 3b). Increases of 1 to $5 \%$ were observed for the NPK and Control treatments under CMCC-CMS, CESM1-BGD and MRI-CGCM3 scenarios.

Similar to the site of Cinzana , simulation of climate change effects on millet grain yield in the site of Sotuba showed an underestimation of crop yield for all scenarios compared to the Baseline for all treatments and both varieties (Figures $4 \mathrm{a}$ and $4 \mathrm{~b}$ ). For the $\mathrm{CHO}$ variety, all of the scenarios with the four treatments estimated low grain yield compared to the Baseline, apart from the Control and NPK treatments for which the CMCC-CMS (Cold-Dry) and CESM1 -BGC (Hot-Dry) yielded higher than the baseline for very low probabilities (Figure 4a). NPK+ Manure treatments and Manure treatment simulated extremely low grain yields compared to the baseline. The lowest grain 
yields were of $150 \mathrm{~kg} / \mathrm{ha}$ for both Control and MANURE, and about $400 \mathrm{~kg} / \mathrm{ha}$ for both NPK and NPK + Manure treatments. Similar to IBV8001 variety in the site of Cinzana, the ANOVA and LSD test revealed significant differences $(\mathrm{P}<0.05)$ among the scenario outputs for all of the treatments (Table 7). Meanwhile, the $\mathrm{CHO}$ variety showed the lowest grain yields under all of the treatments for ACCESS1-0 (Hot-Wet). The decrease in grain yields reached $2 \%$ for NPK under MRICGCM3, and $46 \%$ for Manure under ACCESS1-0 (Figure 4c). The NPK and Control treatments under CMCC-CMS and CESM1-BGD induced increases in the grain yields by 1 to $4 \%$.

As far as SANIONI variety is concerned, all of the scenarios and treatments estimated lower grain yields compared to the Baseline, apart the Control and NPK treatments for which the CMCC-CMS (Cold-
Dry) and CESM1-BGC (Hot-Dry) showed higher grain yield than the Baseline for very low probabilities (Figure 4b). MANURE+NPK and MANURE treatments simulated under all of the scenarios lower grain yields compared to the Baseline. The lowest grain yields were about $100 \mathrm{~kg} / \mathrm{ha}$ for both the Control and MANURE treatments, and about $600 \mathrm{~kg} / \mathrm{ha}$ for both NPK and NPK+ MANURE treatments. For scenario ACCESS1-0 (Hot-Wet), SANIONI variety showed the lowest grain yields under all of the treatments. The ANOVA and LSD test revealed significant differences $(\mathrm{P}<0.05)$ among the scenario outputs for all of the treatments (Table 8). Simulations of the yields for the Control under CMCC-CMS, and MANURE under ACCESS 1 - 0 decreased by $4 \%$ and $46 \%$, respectively (Figure $4 \mathrm{~d}$ ). The Control under CESM1-BGD induced an increase in the grain yields by $4 \%$.
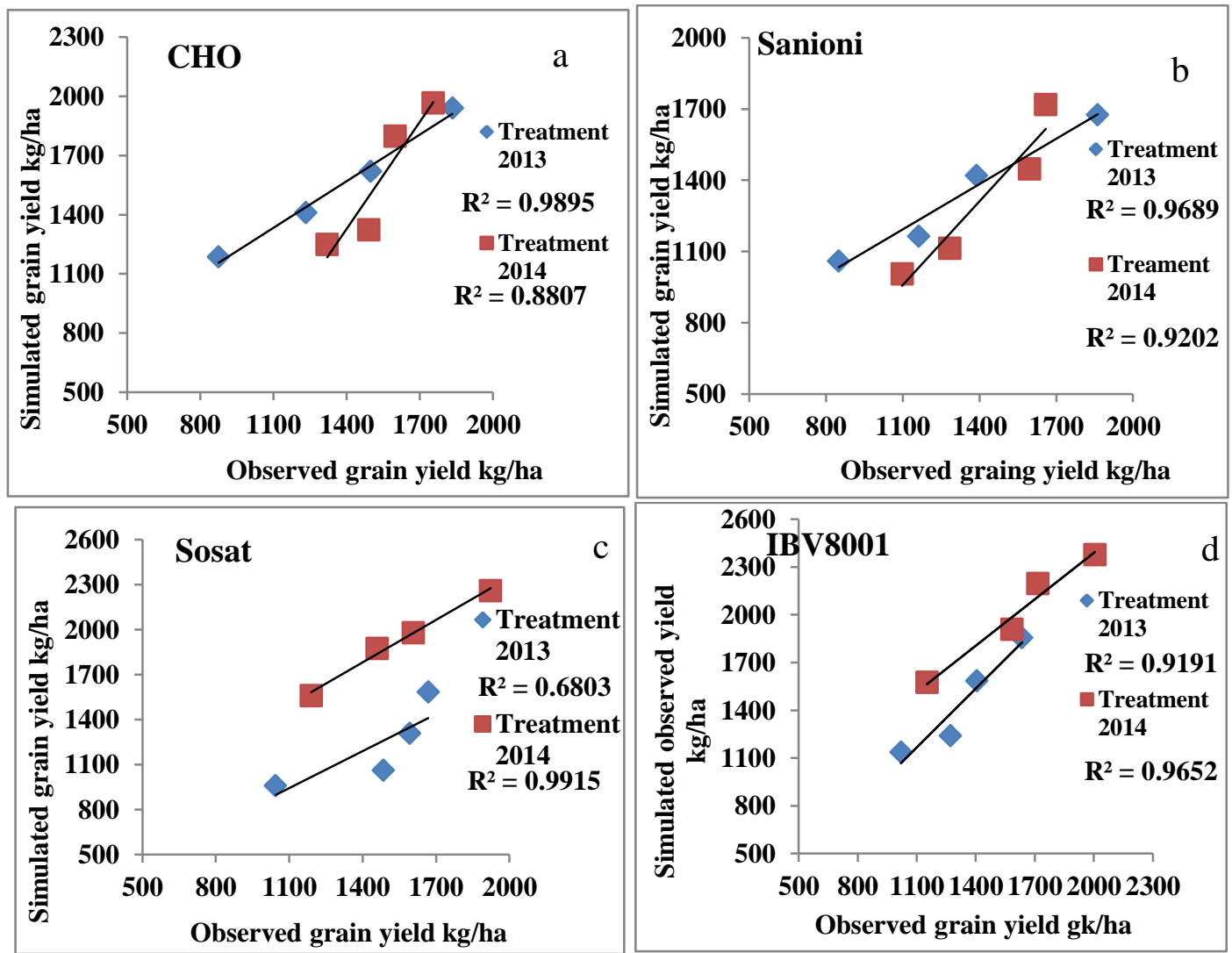

Figure 1: Comparison between simulated and observed grain yields for Sotuba (a and b) and Cinzana (c and d) location with different varieties. 
Table 3: Statistical parameters of simulation performance for the Cinzana location.

\begin{tabular}{lcccc}
\hline Years & Varieties & RMSE \% & RE (\%) & Model Efficiency (\%) \\
\hline \multirow{2}{*}{2013} & Sosat & 19.9 & 5.2 & 14.4 \\
& IBV8001 & 16.9 & 5.7 & 51.9 \\
\hline \multirow{2}{*}{2014} & Sosat & 11.3 & 2.8 & 50.0 \\
& IBV8001 & 21.1 & 4.2 & 41.1 \\
\hline
\end{tabular}

Table 4: Statistical parameters of simulation performance for Sotuba location.

\begin{tabular}{lcccc}
\hline Years & Varieties & RMSE \% & RE (\%) & Model Efficiency (\%) \\
\hline \multirow{2}{*}{2013} & Sanioni & 19.4 & 5.3 & 85.3 \\
& Cho & 20.0 & 5.4 & 14.4 \\
\hline \multirow{2}{*}{2014} & Sanioni & 16.6 & 4.4 & 70.1 \\
& Cho & 20.3 & 5.1 & 68.9 \\
\hline
\end{tabular}

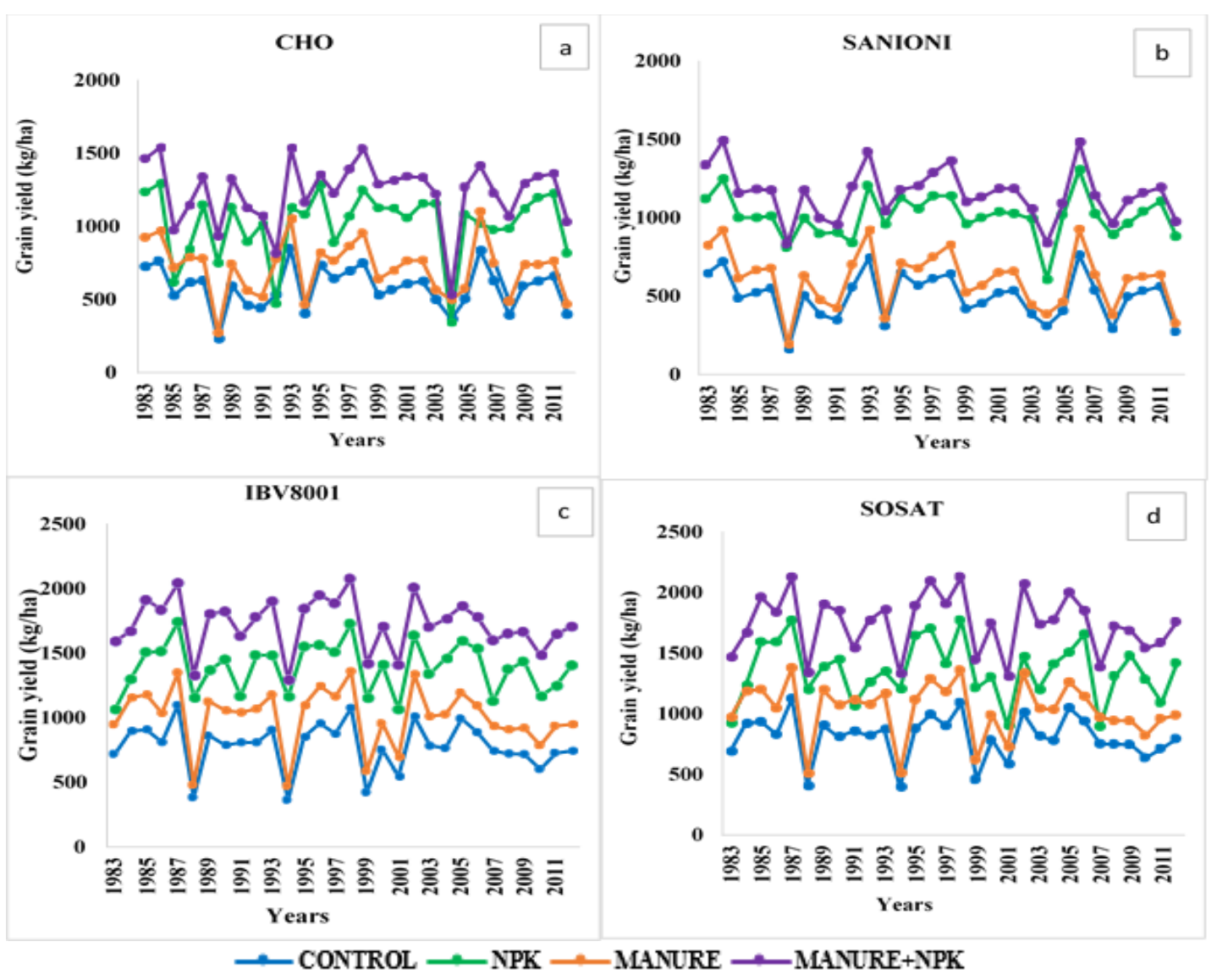

Figure 2: Simulated millet grain yield under historical weather data for Cinzana ( $a$ and $b$ ) and Sotuba (c and d). 
Table 5: Historical average crop yields and coefficient of variation in Cinzana.

\begin{tabular}{lcccc}
\hline & \multicolumn{3}{c}{ IBV8001 } \\
\hline Control & NPK & Manure & Manure+NPK \\
\hline Mean & 784 & 1391 & 1010 & 1726 \\
stdev & 182 & 192 & 228 & 202 \\
CV $(\%)$ & 23 & 14 & 23 & 12 \\
\hline & & & SOSAT & 1743 \\
\hline Mean & 808 & 1357 & 1039 & 242 \\
stdev & 182 & 243 & 225 & 14 \\
CV $(\%)$ & 23 & 18 & 22 & \\
\hline
\end{tabular}

Table 6: Historical average crop yields and coefficient of variation in Sotuba.

\begin{tabular}{|c|c|c|c|c|}
\hline & \multicolumn{4}{|l|}{ CHO } \\
\hline & Control & NPK & Manure & Manure+NPK \\
\hline Mean & 580 & 1015 & 717 & 1232 \\
\hline stdev & 144 & 231 & 187 & 222 \\
\hline \multirow[t]{2}{*}{$\mathrm{CV}(\%)$} & 25 & 23 & 26 & 18 \\
\hline & \multicolumn{4}{|c|}{ SANIONI } \\
\hline Mean & 496 & 1011 & 607 & 1154 \\
\hline stdev & 146 & 138 & 183 & 162 \\
\hline $\mathrm{CV}(\%)$ & 30 & 14 & 30 & 14 \\
\hline
\end{tabular}

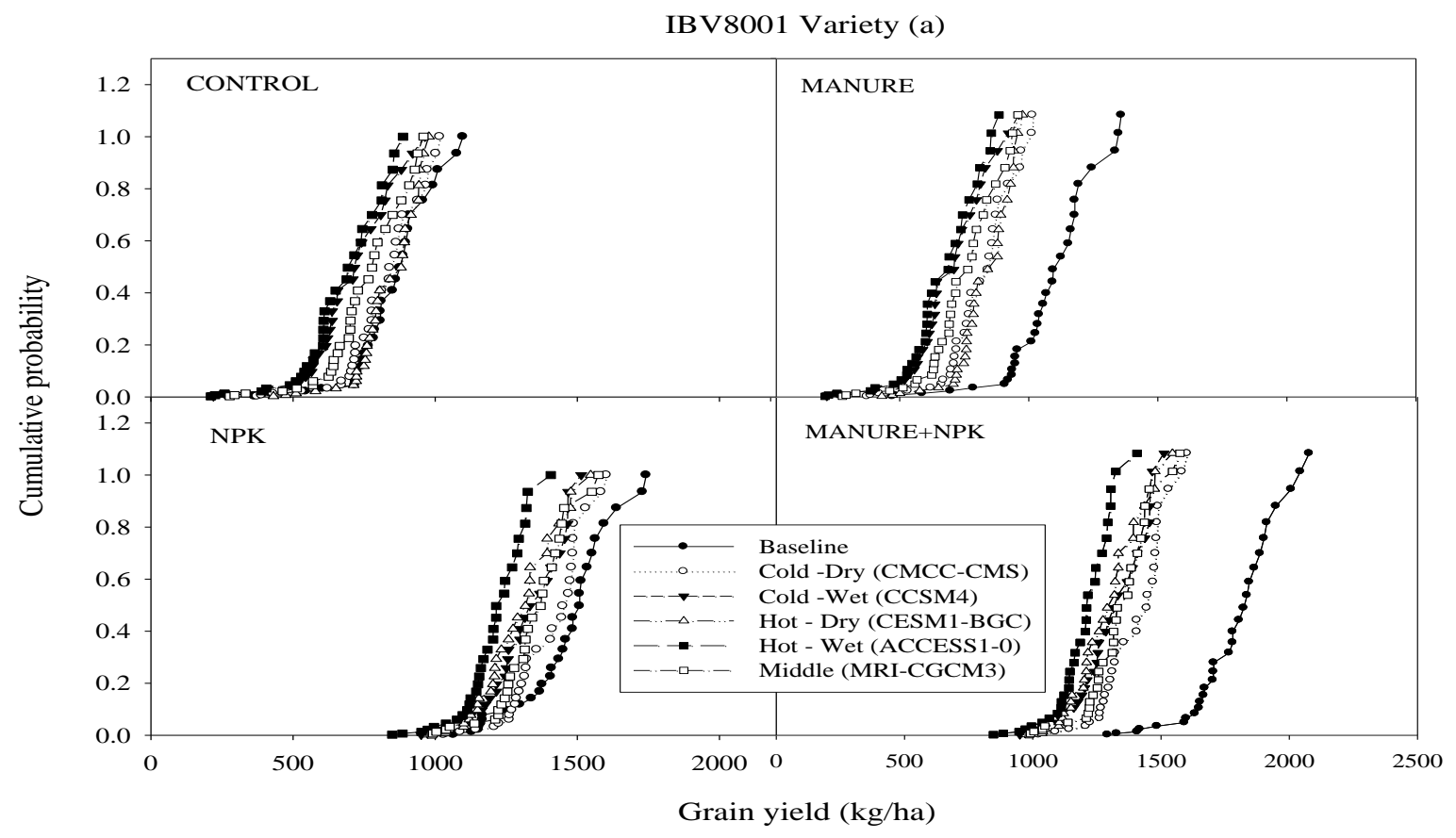




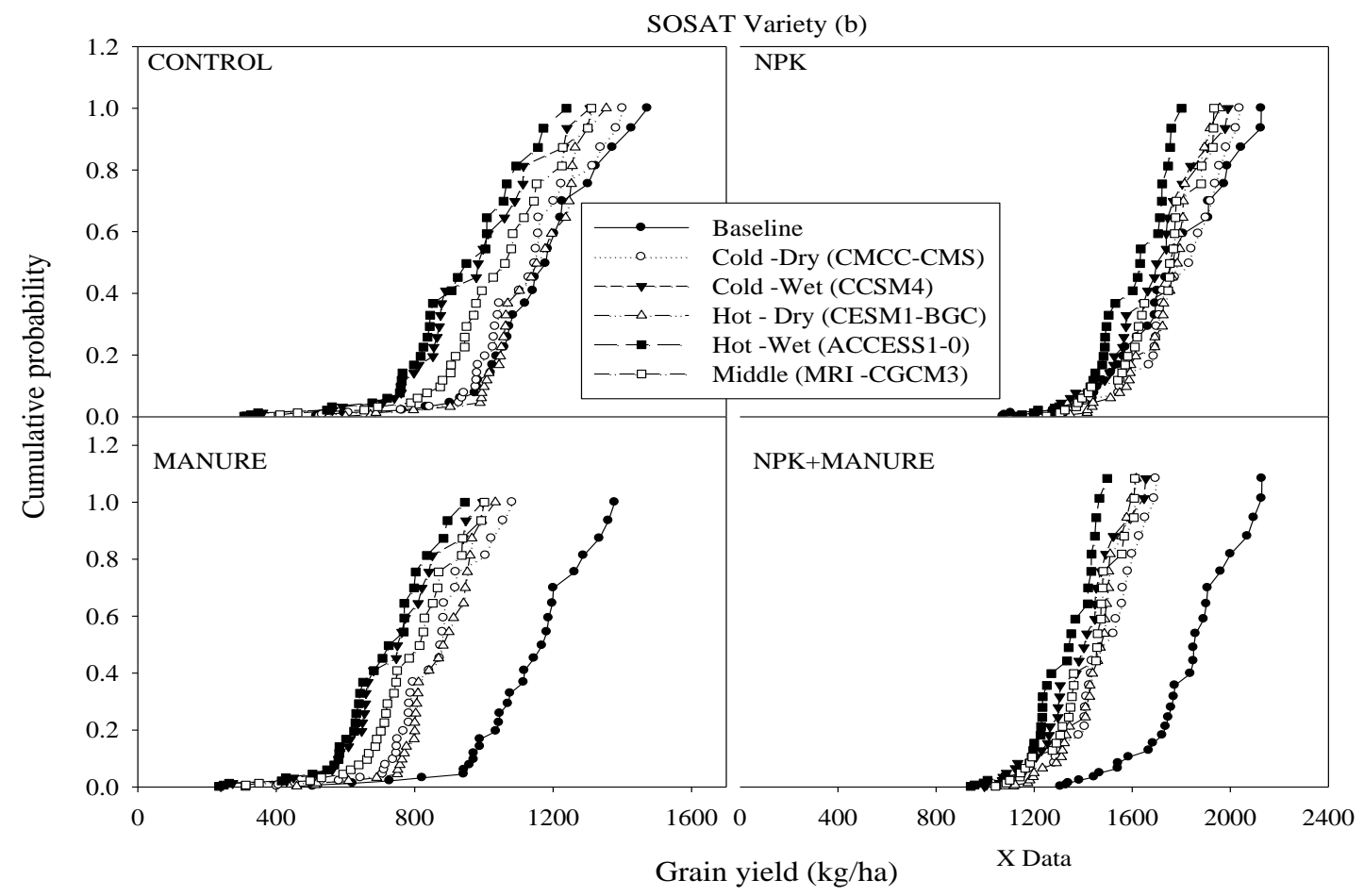

Figure $3 \mathrm{a}$ and $\mathrm{b}$ : Effect of climate change scenarios on millet grain yield for Cinzana.

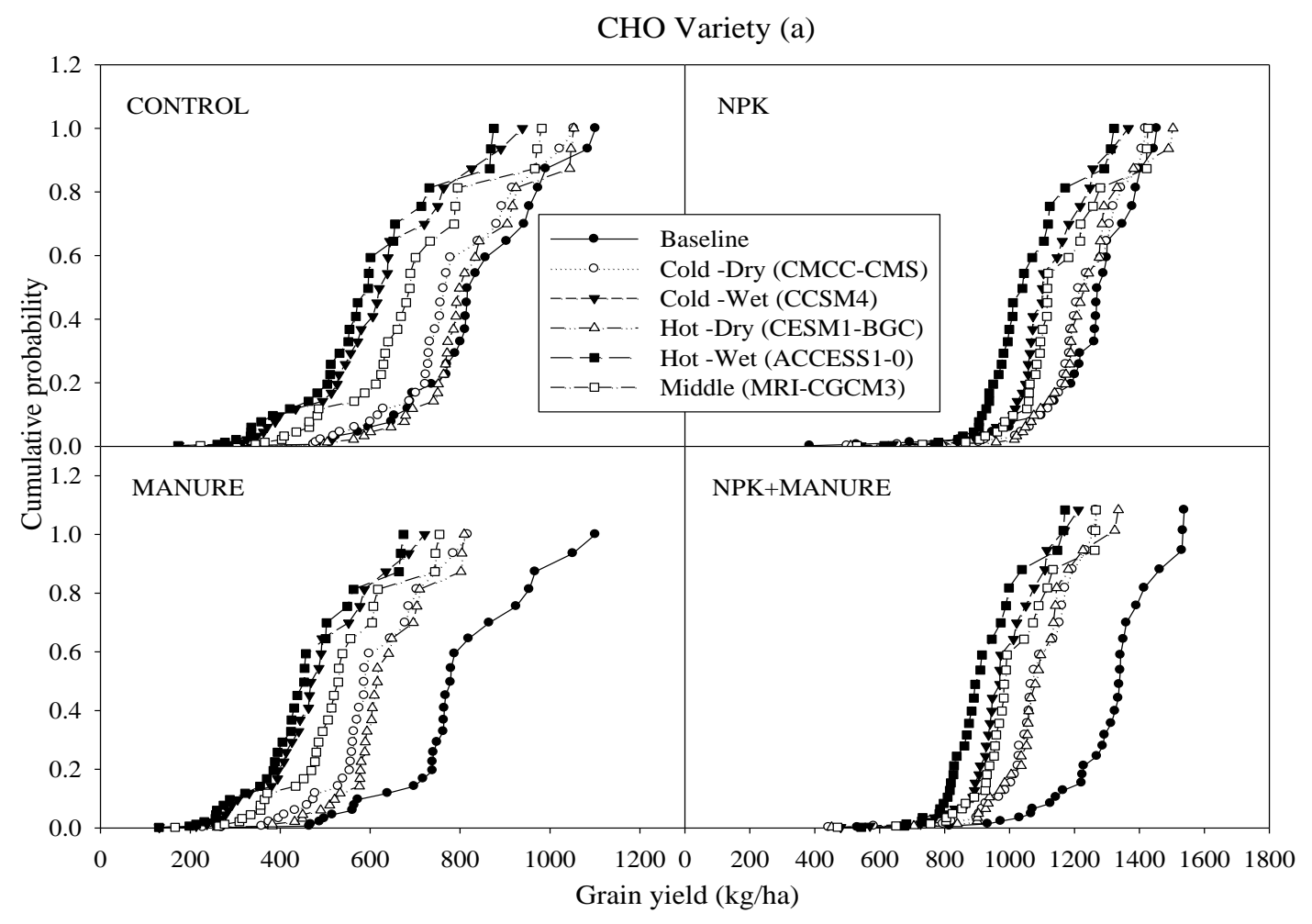




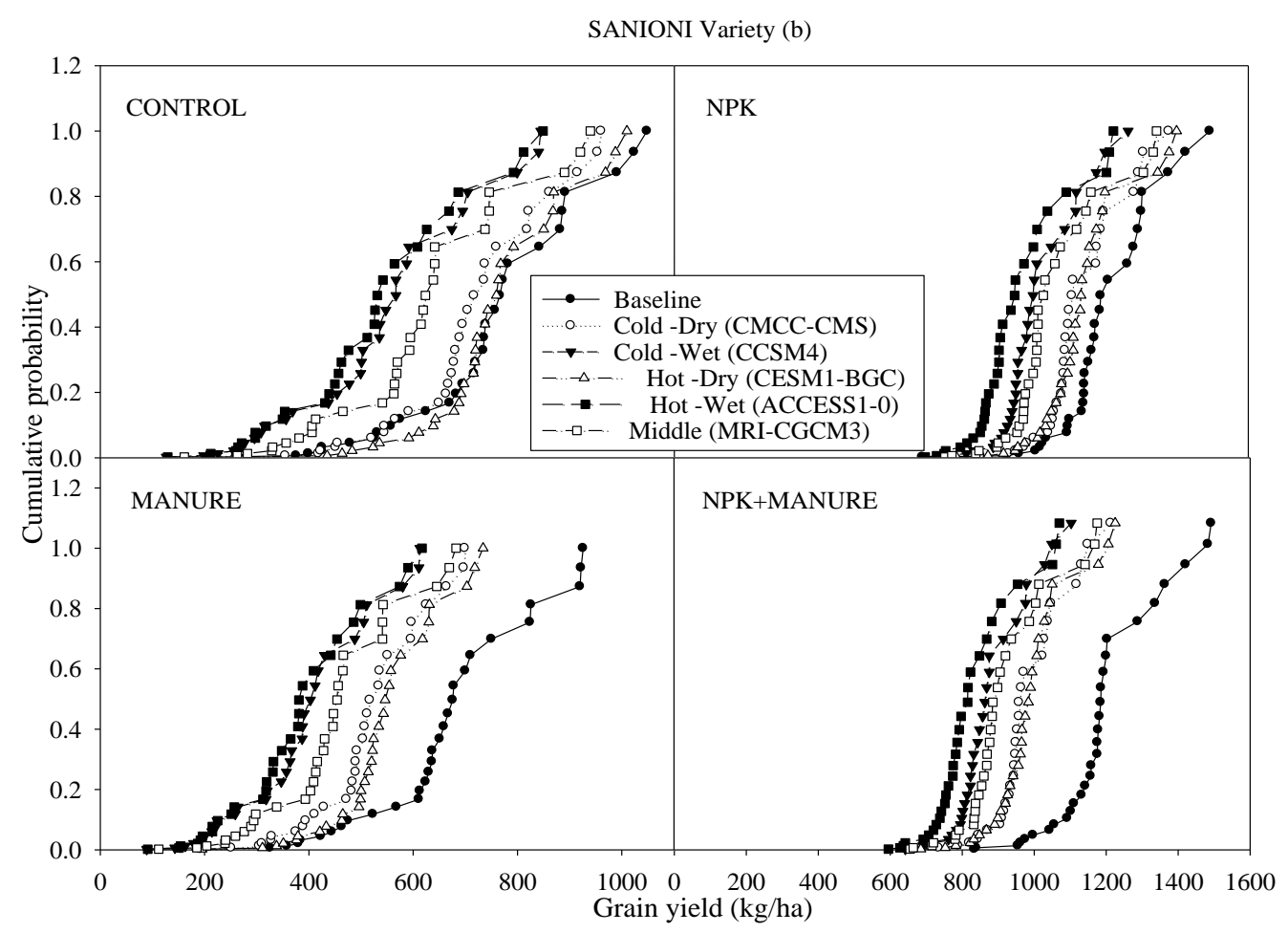

Figure 4 a and b: Effect of climate change scenarios on millet grain yield for Sotuba.

Table 7: Changes in grain yields for different climate scenarios and treatments in Cinzana.

\begin{tabular}{lcccc}
\hline IBV8001 & \multicolumn{5}{c}{ MONTROL } & MANURE & NPK & MANURE+NPK \\
\hline Scenario & Mean & Mean & Mean & Mean \\
\hline Baseline & $784 \pm 182 \mathrm{~A}$ & $1009 \pm 228 \mathrm{~A}$ & $1390 \pm 192 \mathrm{~A}$ & $1726 \pm 2-2 \mathrm{~A}$ \\
Cold/Dry & $757 \pm 167 \mathrm{~A}$ & $754 \pm 168 \mathrm{BC}$ & $1344 \pm 151 \mathrm{AB}$ & $1343 \pm 151 \mathrm{~B}$ \\
Hot/Dry & $624 \pm 190 \mathrm{~B}$ & $620 \pm 190 \mathrm{CD}$ & $1250 \pm 162 \mathrm{BC}$ & $1246 \pm 163 \mathrm{BC}$ \\
Cold/Wet & $778 \pm 142 \mathrm{~A}$ & $775 \pm 142 \mathrm{~B}$ & $1237 \pm 145 \mathrm{BC}$ & $1236 \pm 145 \mathrm{BC}$ \\
Hot/Wet & $605 \pm 179 \mathrm{~B}$ & $601 \pm 179 \mathrm{D}$ & $1158 \pm 133 \mathrm{C}$ & $1154 \pm 134 \mathrm{C}$ \\
Middle & $685 \pm 180 \mathrm{AB}$ & $681 \pm 179 \mathrm{BCD}$ & $1281 \pm 156 \mathrm{AB}$ & $1278 \pm 156 \mathrm{~B}$ \\
\hline P-value & 0.000 & 0.000 & 0.000 & 0.000 \\
\hline SOSAT & & & & \\
\hline & CONTROL & MANURE & NPK & MANURE+NPK \\
\hline Scenario & Mean & Mean & Mean & $1743 \pm 242 \mathrm{~A}$ \\
\hline Baseline & $808 \pm 182 \mathrm{~A}$ & $1038 \pm 25 \mathrm{~A}$ & $1356 \pm 243 \mathrm{~A}$ & $1394 \pm 190 \mathrm{~B}$ \\
Cold/Dry & $787 \pm 168 \mathrm{~A}$ & $785 \pm 169 \mathrm{BC}$ & $1398 \pm 191 \mathrm{AB}$ & $1309 \pm 187 \mathrm{BC}$ \\
Hot/Dry & $655 \pm 193 \mathrm{~B}$ & $651 \pm 193 \mathrm{CD}$ & $1313 \pm 187 \mathrm{AB}$ & $1383 \pm 145 \mathrm{BC}$ \\
Cold/Wet & $808 \pm 141 \mathrm{~A}$ & $805 \pm 142 \mathrm{~B}$ & $1386 \pm 145 \mathrm{AB}$ & $1256 \pm 158 \mathrm{C}$ \\
Hot/Wet & $635 \pm 183 \mathrm{~B}$ & $631 \pm 183 \mathrm{D}$ & $1260 \pm 158 \mathrm{~B}$ & $1343 \pm 173 \mathrm{BC}$ \\
Middle & $714 \pm 180 \mathrm{AB}$ & $711 \pm 180 \mathrm{BCD}$ & $1346 \pm 174 \mathrm{AB}$ & 0.000 \\
\hline P-value & 0.000 & 0.000 & 0.051 & \\
\hline
\end{tabular}


Table 8: Changes in grain yields for different climate scenarios and treatments in Cinzana.

\begin{tabular}{lcccc}
\hline SANIONI & CONTROL & MANURE & NPK & MANURE+NPK \\
\hline Scenario & Mean & Mean & Mean & Mean \\
\hline Baseline & $496 \pm 146 \mathrm{AB}$ & $606 \pm 184 \mathrm{~A}$ & $1170 \pm 211 \mathrm{~A}$ & $1153 \pm 162 \mathrm{~A}$ \\
Cold/Dry & $471 \pm 128 \mathrm{AB}$ & $470 \pm 130 \mathrm{~B}$ & $952 \pm 114 \mathrm{~B}$ & $947 \pm 118 \mathrm{~B}$ \\
Hot/Dry & $347 \pm 140 \mathrm{C}$ & $345 \pm 140 \mathrm{C}$ & $854 \pm 104 \mathrm{C}$ & $845 \pm 109 \mathrm{C}$ \\
Cold/Wet & $507 \pm 120 \mathrm{~A}$ & $505 \pm 122 \mathrm{AB}$ & $956 \pm 118 \mathrm{~B}$ & $951 \pm 121 \mathrm{~B}$ \\
Hot/Wet & $337 \pm 136 \mathrm{C}$ & $335 \pm 136 \mathrm{C}$ & $804 \pm 117 \mathrm{C}$ & $796 \pm 121 \mathrm{C}$ \\
Middle & $400 \pm 141 \mathrm{BC}$ & $399 \pm 142 \mathrm{BC}$ & $887 \pm 124 \mathrm{BC}$ & $880 \pm 128 \mathrm{BC}$ \\
\hline P-value & 0.000 & 0.000 & 0.000 & 0.000 \\
\hline CHO & & & & \\
\hline & CONTROL & MANURE & NPK & MANURE+NPK \\
\hline Scenario & Mean & Mean & Mean & Mean \\
\hline Baseline & $580 \pm 144 \mathrm{~A}$ & $717 \pm 186 \mathrm{~A}$ & $1015 \pm 231 \mathrm{~A}$ & $1231 \pm 221 \mathrm{~A}$ \\
Cold/Dry & $548 \pm 132 \mathrm{~A}$ & $547 \pm 134 \mathrm{~B}$ & $1017 \pm 179 \mathrm{~A}$ & $1012 \pm 180 \mathrm{~B}$ \\
Hot/Dry & $419 \pm 142 \mathrm{BC}$ & $417 \pm 143 \mathrm{C}$ & $930 \pm 155 \mathrm{AB}$ & $920 \pm 157 \mathrm{BC}$ \\
Cold/Wet & $580 \pm 126 \mathrm{~A}$ & $578 \pm 127 \mathrm{~B}$ & $1028 \pm 171 \mathrm{~A}$ & $1023 \pm 172 \mathrm{~B}$ \\
Hot/Wet & $399 \pm 141 \mathrm{C}$ & $397 \pm 141 \mathrm{C}$ & $881 \pm 139 \mathrm{~B}$ & $873 \pm 142 \mathrm{C}$ \\
Middle & $473 \pm 144 \mathrm{BC}$ & $472 \pm 144 \mathrm{BC}$ & $962 \pm 169 \mathrm{AB}$ & $954 \pm 170 \mathrm{BC}$ \\
\hline P-value & 0.000 & 0.000 & 0.007 & 0.000 \\
\hline
\end{tabular}

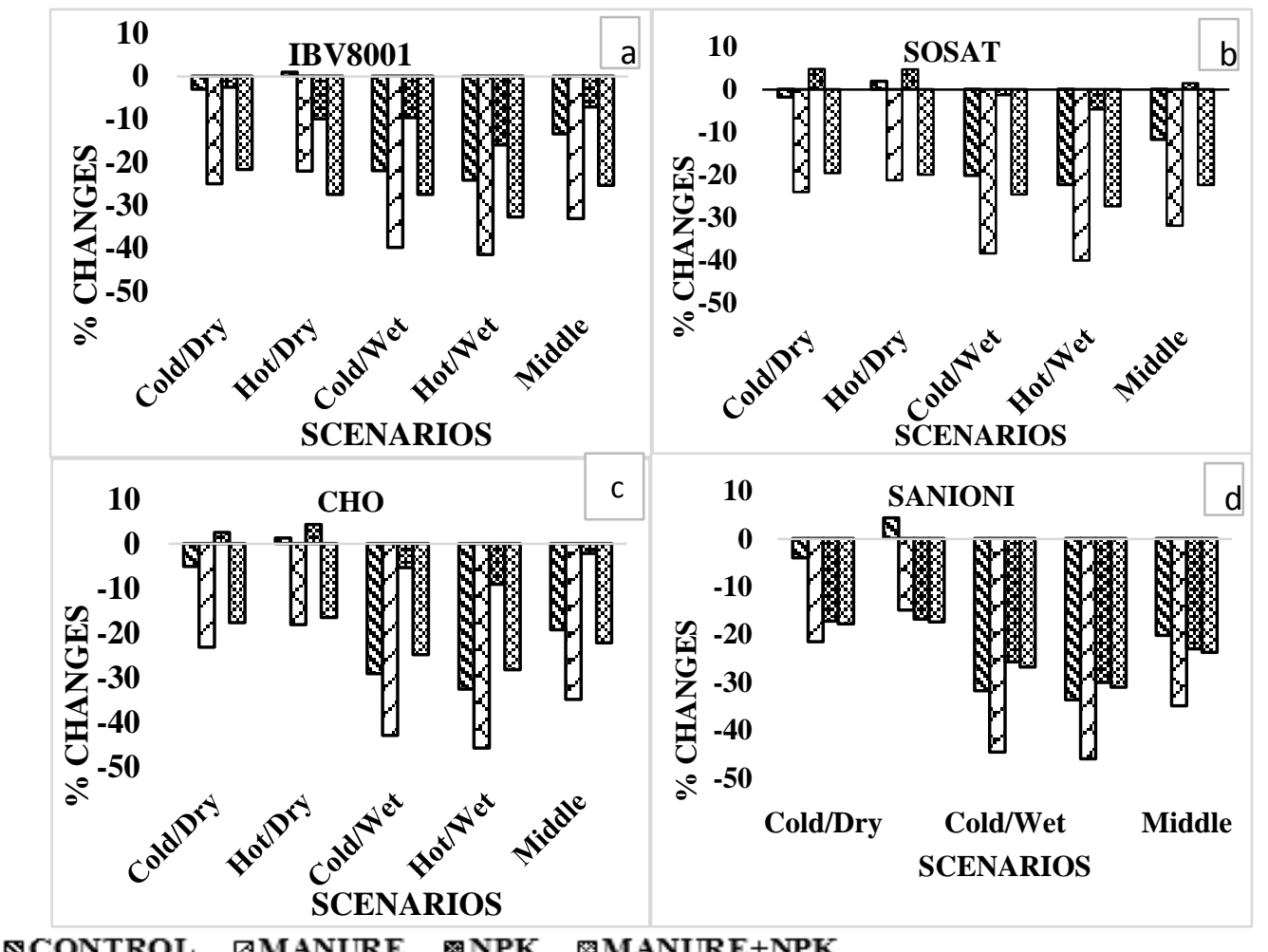

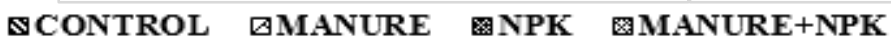

Figure 5: Percentage Changes of Millet Grain Yields for Cinzana ( $a$ and b) and Sotuba (c and d) under Different Scenarios. 


\section{DISCUSSION}

The overestimation of millet grain yield could be explained by the relatively even rainfall distribution throughout the season in 2013 and 2014, when very erratic rainfall patterns were observed with heavy downpours alternating with long early cessation or dry spell of rains (Traoré et al., 2010). The same authors found out that, these discrepancies in the performance of the model could be explained by the poor assessment of the soil and crop water status during the reproductive and maturation phases. Therefore, sensitivity analysis showed that the response of the model is quite dependant on parameters such as runoff coefficients, rooting depth and soil water holding capacity, none of which were measured during our experimental trials.

Based on the regional climate change conditions of the two agro-ecological zones, pearl millet has been simulated using DSSAT crop model. The results showed that the simulated achieved higher potential yield compared compared to the observed yields. The statistical parameters (Tables 3 and 4) suggest that the overall performance of the DSSAT model in the simulation of the effect of mineral and organic fertilizer amendments under rainfed pearl millet production is good and able to project grain yields with high accuracy. And the analyses indicated good performance of the model. Preferably the value of the relative error would be $0 \%$ indicating one to one mapping between simulates and observed values. Therefore, with regards to the agronomic conditions for the observed yields and simulated cannot make a one to one mapping possible, then it can be argued that, the value relative error (RE) indicates good performance of the model. However, for the perfect model, a $100 \%$ value should be observed for a model efficiency. High percentage values indicate good performance of the model, thus the results of the model efficiency for the sites of Sotuba and Cinzana indicate an overall good fit of the model for all of the varieties.

An average relative error between (27.1 and 2.8\%) for the site of Cinzana and for Sotuba (15.3 and 4.4\%) which is < $30 \%$ indicates good correlation between observed and simulated yields. Since the DSSAT model was run using real field conditions, hence, it does not account for yield loss caused by harvest practices, diseases and pest and birds attacks; it can then be concluded that variations between observed and simulated is sufficiently accounted. The yield differences can also be attributed to soil types and degradation caused by unsustainable agronomic practices. However, the same result was found in a study on rice simulation carried out by Oteng-Darko et al. (2012) where good correlation was found between observed and simulated yields with an average relative difference of $12.28 \%(<30 \%)$.

The results showed that millet yield responded to the different historical climatic conditions under all treatments. In line with the experimental observed data, the highest historical grain yields were achieved when the combination NPK +Manure treatments was applied. This shows the beneficial effect of combined application of organic and mineral fertilizer inputs as integrated soil management for Lixisol fertility. The relative increase in yield by NPK+MANURE treatment could be probably attributed to the improvement of soil structure, nutrient retention and water for plant use (Arunah et al., 2006). The study showed how much of the year-to-year variability in crop yield was associated with climate variability within the study areas. As reported by Tingem et al. (2008) in Cameroon, this study also found that millet yield variability was explained only by a complex relationship between both temperature and precipitation variability. In conjunction with fluctuation in agricultural production as affected by climate variability, low food stocks can particularly contribute to changes in food price. Also location with high crop yield variability would disproportionately contribute to this effect especially if it is also the major granary.

In Mali, semi-arid to arid conditions depend on the seasonal rainfall distribution. The study showed that an important climatic feature which is high annual variability in grain yield in Sotuba (Sudanian zone) than the 
site of Cinzana (Sahelian zone). However, this may explain that the actual effect on millet grain yields variability depends on the agroecological zones for the specific crop and management strategy adopted. Pearl millet is more adapted in the Sahelian zone than the Sudanian zone.

Figure 3 ( $\mathrm{a}$ and $\mathrm{b}$ ) and Figure 4 ( $\mathrm{a}$ and b) showed the simulated effects of the scenarios of rainfall and temperature changes on millet grain yields for the period 2040 to 2069. The changes are computed as averages across the 29 GCMs simulations for each agro-ecological zone. Future climate projections from GCMs showed decreasing millet grain yields over 2040 - 2069 compared to the Baseline period (1983 2012) at both sites. Simulations showed higher grain yields under historical weather data compared to the situation with the changing climate future scenarios. The study showed that an increase in temperature and precipitation would be the main unfavourable driver of the future change in the pearl millet yields. The effects of climate change and variability are more acute in the Sudanian zone for both varieties and treatments. This may be explained by the fact that, in the Sudanian zone, a semi-arid area with mean annual rainfall between $800-1100 \mathrm{~mm}$, and the increase in temperature of that amount of rainfall may provoke excessive and useless soil moisture damageable to the pearl millet production. These findings are consistent with previous studies for sorghum using another crop simulation model (Sultan et al., 2014) and also for millet and sorghum (Sultan et al., 2013) and for maize (Schlenker and Lobell, 2010). All of these findings confirmed that temperature increase is the main driver decreasing the yield for future climate change. High temperatures generally decrease the yield by increasing the plant growth rate, reducing thus the period available for biomass production (Chmielowski et al., 2004; McCarthy et al., 2012).

Furthermore, the result showed that millet grain yields respond positively i.e. an increase of grain yield under CMCC-CMS and CESM1-BGC scenarios than the three others. The increases in grain yield for those scenarios were observed under the Control and NPK treatments. This may be explained by the fact that in CMCC-CMS, the increase in temperature by $1.4{ }^{\circ} \mathrm{C}$ and no change in rainfall may not affect the grain yields under the Control and NPK treatments. Similarly, increase in temperature by $2.4{ }^{\circ} \mathrm{C}$ and $10 \%$ decrease in rainfall (CESM1-BGC scenario) may also not affect the grain yield. Millet yield decreased significantly under climate change scenarios, particularly under NPK treatment and the ACCESS1-0 scenario, which is based on increase of both in temperature and precipitation $\left(2.4{ }^{\circ} \mathrm{C}\right.$ and $30 \%$, respectively) for the period $2040-2069$ (Figure 5). As indicated in previous researches (McCarthy et al., 2010; Eyshi Rezaie et al., 2013), this may be due to the high average temperature and the short phenological phase duration of pearl millet, especially in critical growth stages such as grain filling period under mineral fertilization. The frequency of extreme events like warm day and warm night could therefore affect the productivity of millet in the Sudanian and Sahelian zones. In addition, excessive rainfalls (about 30\% in this study) can have severe impacts on millet production through the reduction of nutrient availability due to soil loss and fertilizer leaching.

\section{Conclusion}

The output of this study clearly showed that the modele DSSAT simulated millet crop growth and yields with good accuracy. However, the study indicated crop simulation models as potential decision making agronomic tools to understand millet crop biodynamism under variable climatic conditions of agriculture. Moreover, the model evaluation over the two agro-ecologies enhances our knowledge to build resilience in various situations and to pick variability and rainfall regimes, prove a better tool for crop yield and rainfall forecast of the regions. The statistical parameters suggest that the overall performance of the model DSSAT in simulating chemical and organic fertilizer amendments in rainfed and irrigated maize is 
good and able to predict biomass and grain yields with high accuracy. The study showed that increase in temperature and rainfall in future would affect millet grain yield in the Sudanian and Sahelian zones.

\section{ACKNOWLEDGMENTS}

The authors are grateful to the participant of staff in IER (Institute Economic Rural) of Sotuba and Cinzana and also the Staff of Aghrymet for their kind assistance regarding data collection of this study. The paper is based on the first author's Ph.D. thesis submitted to the Kwame University Nkrumah of Science and Technology (KNUST) Kumasi, Ghana. The Ph.D. programme was sponsored by the West African Science Service Centre on Climate Change and Adapted Land Use (WASCAL).

\section{REFERENCES}

Ali M H, Amin MGM, Islam AKMR. 2004. Comparison of various methods for estimating reference crop evapotranspiration. Journal Bangladesh Agriculture University, 2(2): 313-324.

Arunah L, Chiezey UF, Aliyu L, Babaji BA, Odion EC, Sani BM. 2006. Application of Inorganic Fertilizers and Poultry on Sorghum-crude Protein Yield and Growth Parameters. Proceeding of the $2^{\text {nd }}$ National Conference on Organic Agriculture in Nigeria, 114-117.

Barrios S, Ouattara B, Strobl E. 2008. The impact of climatic change on agricultural production: Is it different for Africa? Food Policy, 33(4): 287-298.

Butt TA, Mccarl BA, Angerer J, Dyke PT, Stuth JW. 2005. The Economic and Food Security Implications of Climate Change in Mali. Climatic Change, 68: 355-378.

Challinor A, Wheeler T, Garforth C, Craufurd P, Kassam A. 2007. Assessing the vulnerability of food crop systems in Africa to climate change. Climatic Change, 83(3): 381-399.

Chmielewski FM, Muller A, Bruns E. 2004. Climate changes and trends in phenology of fruit trees and field crops in Germany,
1961-2000. Agricultural and Forest Meteorology, 121: 69-78.

Chuku CA, Okoye C. 2009. Increasing resilience reducing vulnerability in subSaharan African agriculture: strategies for risk coping and management. African Journal of Agricultural Research 4: 1524-1535.

Dai A, Trenberth KE. 2004. The Diurnal Cycle and its Depiction in the Community Climate System Model. Journal of Climate, 17(5): 930-951.

DNS. (Enquête Agricole De Conjoncture). 1995. 1994-1995 Résultats Définitifs, Bamako. DNA, Août 1995, 52p.

Dust M, Baran N, Errera G, Huston JL, Mouvet C, Schafet H, Vereecken H, Walker A. 2000. Simulation of water and solute transport in field soils with the LEACHP model. Agriculture Water Manage, 44: 225-245.

FAO. 1993. World Soil Resources. An explanatory note on the FAO World Soil Resources Map at 1:25.000.000 scale, 1991. Rev. 1993. World Soil Resources Reports \#66. FAO: Rome.

Eyshi Rezaie E, Gaiser T, Siebert S, Ewert F. 2013. Adaptation of Crop Production to Climate Change by crop Substitution. Mitigation and Adaptation Strategies for Global Change, 013: 9528-1.

Hoogenboom CH, Jones JW, Porter G, Boote KJ, Batchelor WD, Hunt LA, Wilkens PW, Singh U, Gijsman AJ, Ritchie JT. 2003. The DSSAT Cropping System Model. European Journal of Agronomy, 18: $235-265$.

Hoogenboom G, Wilkens PW, Tsuji GY. 1999. DSSAT version 3 (4). International Consortium for Agricultural Systems application. University of Hawaii Honolulu, HI, 234235.

IPCC. 2013. Summary for Policymakers. In: T.F. Stocker Et Al. (Editors), Climate Change 2013: The Physical Science Basis. Contribution of Working Group I to The Fifth Assessment Report

Jones JW, Hoogenboom G, Porter CH, Boote KJ, Batchelor WD, Hunt LA, Wilkens 
PW, Singh U, Gijsman AJ, Ritchie JT. 2003. The DSSAT Cropping System Model. European Journal of Agronomy, 18: 235-265.

Lecina S, Martinez-Cob A, Perez PJ, Villalobos FJ, Baselga JJ. 2003. Fixed versus variable bulk canopy resistance for reference ET estimation using the Penman-Monteith equation under semiarid conditions. Agricuture Water Manage, 60: $181-198$.

Liu HL, Yang JY, Drury CF, Reynolds WD, Tan CS, Bai YL, He P, Jin J, Hoogenboom G. 2011. Using the DSSATCERES- Maize Model to Simulate Crop Yield and Nitrogen Cycling in Fields Under Long-Term Continuous Maize Production. Nutrient Cycling in Agroecosystems, 89: 313-328.

Loague K, Green RE. 1991. Statistical and graphical methods for evaluating solute transport models: Overview and application. Journal of Contaminant Hydrology, 7: 51-73.

Lobell DB, Burke MB. 2008. Why are agricultural impacts of climate change so uncertain? The importance of temperature relative to precipitation. Environment Research Letters, 3: 8.

McCarthy DS, Vlek PLG, Bationo A, Tabo R. and Fosud M. 2010. Modeling Nutrient and Water Productivity of Sorghum in Smallholder Farming Systems in a SemiArid Region of Ghana. Field Crops Research, 118: 251-258.

McCarthy DS, Vlek PLG. 2012. Impact of Climate Change on Sorghum Production under Different Nutrient and Crop Residue Management in Semi-Arid Region of Ghana: a Modeling Perspective. Journal of African Crop Science, 20: 275-291.

Mukhtar A, Fayyaz UH. 2011. APSIM and DSSAT Models as Decision Support Tools. $19^{\text {th }}$ International Congress on Modelling and Simulation, Perth, Australia, 12-16 December 2011 Adepartment of Agronomy, PMAS-Arid Agriculture University, Rawalpindi, Pakistan.
Muller C, Bondeau A, Popp A, Waha K, Fader M. 2010. Climate change impacts on agricultural yields. Background note to the World Development Report 2010. Potsdam Institute for Climate Impact Research, Potsdam.

Oteng-Darko, Kyei-Baffour N, Ofori E. 2012. Simulating Rice Yields Under Climate Change Scenarios Using the Ceres-Rice Model. African Crop Science Journal, 2: $401-408$.

Oxfam. 2007. Understanding Gender Differential Impacts of Tsunami and Gender Mainstreaming Strategies in Tsunami Response in Tamil Nadu. Oxfam: India. no city.

Ritchie T, Alagarswamy G. 1989. Simulation of Sorghum and Pearl Millet Phenology. In Modeling the Growth and Development of Sorghum and Pearl Millet, Virmani SM. Tandon HLS, Alagarswamy G (eds). Research Bulletin No. 12. ICRISAT: Patancheru, Andhra Pradesh, India: 24-26

Roudier P, Sultan B, Quirion P, Berg A. 2011. The impact of future climate change on West African crop yields: What does the recent literature say? Global Environmental Change, 21(3): 10731083.

Schlenker W, Lobell DB. 2010. Robust negative impacts of climate change on African agriculture. Environmental Research Letters, 5(1): 014010.

Schwartz P, Randall D. 2003. An Abrupt Climate Change Scenario and Its Implications for United States National Security. Accessed On 20 July 2009. Http://Www.Greenpeace.Org/Raw/Conte nt/International/Press/Reports/AnAbrupt-Climate-Changescena. Pdf.

Sultan B, Janicot S. 2003. The West African Monsoon Dynamics. Part II: The "Preonset" and "Onset" of the Summer Monsoon. Journal of Climate, 16: 34073427.

Sultan B, Roudier P, Quirion P, Alhassane A, Muller B, Dingkuhn M, Ciais $\mathrm{P}$, Guimberteau M, Traore S, Baron C. 2013. Assessing climate change impacts 
on sorghum and millet yields in the Sudanian and Sahelian savannas of West Africa. Environmental Research Letters, 8(1): 014-040.

Sultan B, Guan K, Kouressy M, Biasutti M, Pian C, Hammer GL, McLean G, Lobell DB. 2014. Robust Features of Future Climate Change Impacts on Sorghum Yields in West Africa. Environmental Research Letters, 9: 104006.

Tingem M, Rivington M, Colls J. 2008. Climate variability and maize production in Cameroon: Simulating the effects of extreme dry and wet years. Singapore, Journal Tropical Geography, 29: 357-370.

Tingem M, Rivington M. 2009. Adaptation for crop agriculture to climate change in Cameroon: Turning on the heat. Mitigation and Adaptation Strategies for Global Change, 14(2): 153-168.

Traore B. 2014. Thesis on Climate change, climate variability and adaptation options in smallholder cropping systems of the Sudano - Sahel region in West Africa. C.T. de Wit Graduate School of Production Ecology and Resource Conservation; 173.
Traore B, Corbeels M, Van Wijk MT, Rufino MC, Giller KE 2013. Effects of Climate Variability and Climate Change on Crop Production in Southern Mali. European Journal of Agronomy, 49: 115- 125.

Traoré S B, Alhassane A, Muller B, Kouressy M, Somé L, Sultan B, Oettli P, Ambroise C S, Sangaré S, Vaksmann M, Diop M, Dingkhun M, Baron C 2010. Characterizing and Modelling the Diversity of Cropping Situations Under Climatic Constraints in West Africa. Atmospheric Science Letters, 12(1): 8995

Trenberth KE, Jones PD, Ambenje P, Bojariu $\mathrm{R}$, Easterling D, Tank AK, Parker D, Rahimzadeh F, Renwick JA, Rusticucci M. 2007a. Observations: Surface and Atmospheric Climate Change. Chapter3 of Climate Change 2007. In The Physical Science Basis. Contribution of Working Group I to The Fourth Assessment Report of the Intergovernmental Panel On Climate Change, Solomon S, Qin D, Manning M, Marquis M, Averyt KB, Tignor M, Miller HL, Chen Z. (eds.). Cambridge University Press: Cambridge, UK and New York; 235-336. 